\title{
Policy entrepreneur and social policy innovation in China
}

\author{
Yapeng Zhu ${ }^{*}$ and Diwen Xiao
}

\author{
* Correspondence: \\ Ipszyp@mail.sysu.edu.cn \\ Center for Chinese Public \\ Administration, School of \\ Government, Sun Yat-sen University, \\ No. 135, Xingangxi Road, \\ Guangzhou, Guangdong, China
}

\begin{abstract}
Fostering policy innovation at the local level and spreading the successful practice have been pervasive features of policy making in postreform China. The existing literature explains why the local government launches innovations and what enables these innovations. However, little research has been done on the emerging process of the new ideas and the process in which new policies are accepted by stakeholders. This article is an case study based on the policy innovation in the health insurance system in the city of Nanguo. We applied policy entrepreneur theory to analysis of the innovation process of the Chinese local government, with a special focus on the key agents and their interaction in the innovation process. The study reveals that bureaucrats play the role of policy entrepreneurs to elevate the rank of the organization and to acquire more administrative resources. With knowledge and technical expertise, these bureaucrats construct policy agendas; suggest innovative ideas; design policy programs; and acquire the support and approval of other stakeholders, especially local leaders, by strategies such as marketing, alliances, and fostering political achievements. By these means, they facilitate the formation and further development of the innovation policy.

Keywords: Policy innovation; Social policy; Policy entrepreneur; Administrative bureaucrats
\end{abstract}

\section{Background}

Fostering policy innovation at the local level and diffusing successful practices to higher administrative level, even nationwide, are pervasive features of policy making in postreform China (Heilmann 2007, 2008; Zhu 2012, 2013). ${ }^{1}$ Local policy innovations in China have drawn enormous academic interest. The existing literature addresses the institutional possibilities, the incentive mechanism of policy innovation, and factors that hinder or facilitate policy innovation. These studies explain why local governments initiate policy innovation and what enables innovations. However, the incentive, willingness, and possibilities of policy innovation cannot explain the success of innovative policies.

Policy innovation is not only an outcome of internal and external pressures (Glor 2001; Rogers 1995) but also undergoes a dynamic and complicated political process (Roberts 1992; Mintrom 1997). This process includes conceptualizing of ideas, program design, acquiring approval and support from policy participants, and finally the successful implementation of the policy. The essence of policy innovation is accomplishing policy objectives in innovative ways that bring opportunities, risks, and

\section{Springer}

(c) 2015 Zhu and Xiao. Open Access This article is distributed under the terms of the Creative Commons Attribution 4.0 International License (http://creativecommons.org/licenses/by/4.0/), which permits unrestricted use, distribution, and reproduction in any medium, provided you give appropriate credit to the original author(s) and the source, provide a link to the Creative Commons license, and indicate if changes were made. 
challenges to the policy participants. Little attention has been paid to the process in which innovative ideas are transformed into policy practices. Inadequate explanation has been given to who the key agents are that promote policy innovation and why decision makers are willing to risk implementing the innovative policies. Taking the process of health insurance system innovation in Nanguo City as a case study, this article reveals the role that policy entrepreneurs play in this process, with a special focus on their motivation to foster the innovation, the strategies they take, and their interaction with other stakeholders.

\section{Literature review and theoretical framework Local policy innovations in China}

Since the Reform and Opening, policy innovations launched by local government in all aspects have provided valuable experience in effective governance for China. Existing research focuses mainly on the following aspects pertaining to policy innovation.

\section{Institutional background and possibilities}

Decentralization, especially the decentralization of taxation, has been considered the main institutional factor for cultivating local government policy innovation (Heilmann 2008; Qian and Roland 1998; Jin et al. 2005). Local governments have gained a certain degree of autonomy and promoted policy experimentation driven by local interests (Shi and Xie 2002; Qiu and Xu 2004; Walder 1995, 1998; Oi 1992, 1995, 1998).

\section{Motivation and incentive}

The competitive promotion system for local cadres and the execution of administrative services provide the incentives that make local governments foster policy innovations. First, it encourages local leaders to promote policy innovation in order to get ahead in promotion competition (Zhou 2008; Zhang et al. 2007). Second, it urges local leaders to work out corresponding policy for some serious issues that could bring failure through veto (Saich 2008; Wang and Wang 2009).

\section{Innovation types and characteristics}

Some studies show that governments at the county and municipal levels are more active in promoting policy innovation; moreover, political elites inside local governments generally initiate policy innovations (Chen and Yang 2009). These pioneering practices are distinctively low risk and political periodicity (Wu et al. 2007; He 2007). Moreover, the impact factors that trigger innovations and the types of innovations are multifaceted (Wu et al. 2013; Wu et al. 2011; Yang 2008, 2011).

In sum, the existing literature pays more attention to the institutional background, motivation and incentive mechanisms, and categorization of local policy innovations. However, there are some limitations. First, the policy innovation process has been neglected. Local governments have the objective of innovation but not necessarily the capacity. Moreover, innovation cannot be achieved overnight. Second, the complexity within the local governmental system has been neglected. Existing studies have either neglected different interests or roles of the bureaucrats inside local governments or obscured these differences. In this literature, local governments are usually taken as a totality without internal divergences (Chen 2002). In contrast, some research has attributed innovations to particular liberal individuals, especially top leaders; their ideas and interests are considered the key factors for policy innovations at the local level (Cheung et al. 1998). 
To better understand policy innovations in China, one must focus on the dynamic process of policy innovation as well as the participants who successfully implement innovative policy programs. Policy entrepreneur theory focuses on key agents who promote the policy innovation and thus serve as a sound theoretical tool for understanding policy innovations. A few scholars have addressed the role of policy entrepreneurs; however, they focus on policy entrepreneurs outside governments (Mertha 2009; Zhu 2008) and neglect policy entrepreneurs inside governments. Under an authoritative regime, actors inside the government play the leading role in the decision-making process. A few exceptions focus only on political leaders and ignore bureaucrats, who make up the main body of local governments (Hammond 2013; Zhu 2012, 2013).

\section{Policy entrepreneurs and policy innovation: an analytic framework}

Policy entrepreneur theory argues that the mind-set, capacity, and political skills of individuals are crucial in promoting policy innovations. The literature on policy entrepreneurs generally deems their dedication to innovation to be the key element of policy entrepreneurship. The policy entrepreneur model on policy innovation is based on three questions: who are policy entrepreneurs, which factors influence policy entrepreneurs involved in policy innovation, and how do policy entrepreneurs put innovative ideas into practice.

\section{Types and features of policy entrepreneurs}

Policy entrepreneurs are those who alter the existing ways that public resources are allocated by mobilizing organizational and collective power (Lewis 1980). In the policy innovation process, which is full of risks, policy entrepreneurs are dedicated to investing time, energy, and even property to break the political equilibrium, sell their ideas to others, and transform the ideas into policy programs (Kingdom 1995; Schneider and Teske 1992). Policy entrepreneurs could be elected politicians, leaders of interest groups, or members of research institutions (Kingdom 1995; Lewis 1980; Riker 1986; Weissert 1991; Zhu 2008). They generally share the following characteristics. First, they are capable and willing to take on risks and responsibilities (Kingdom 1995). Second, they have the expertise and persistence for policy innovation (Weissert 1991). Third, they are critical thinkers, skillful managers, and excellent leaders (King and Roberts 1992). Fourth, policy entrepreneurs can promote and sustain the long-term development of innovative policy programs, which makes policy entrepreneurs different from other policy actors (Roberts 1992).

\section{Factors that influence policy entrepreneurs' involvement}

Policy-entrepreneur involvement is constrained by various internal and external conditions. (1) Internal and external policy environment: Policy-related information, political risks, and mutual trust among social groups vary considerably in the external environment that policy entrepreneurs face (Huitema and Meijerink 2010). The internal environment in which policy entrepreneurs are connected is also prominent. The behaviors and incentives of policy entrepreneurs can be determined by the organization that policy entrepreneurs belong to and the position that policy entrepreneurs hold in the political system (Schneider 1989; Lewis 1980). Additionally, the position that policy entrepreneurs hold determines whether they can establish effective social networks, communication channels, and opportunities for policy innovation (Kingdom 1995). (2) Individual capacities: First, in order to take action, 
policy entrepreneurs rely on their own personal resources, such as expertise, leadership, teamwork, personal reputation, social networks, and persistence (Mintrom and Vergari 1996). Second, they can capture fleeting opportunities to promote policy innovation (Kingdom 1995). Finally, they are able to establish political alliances to ensure policy innovation success (Doig and Hargrove 1990). (3) Incentives: Encouraged by a higher social reputation, a more promising political career, and easier enactment of legislation, policy entrepreneurs tend to be involved in policy issues that draw public attention and are closely related to public benefits (Teodoro 2009; Schneider and Teske 1992).

\section{Strategies for promoting policy innovations}

The policy innovation process can be divided into three stages: idea conceptualization, policy program design, and policy implementation (Roberts 1992). Policy entrepreneurs need to apply various strategies in different stages to make certain innovative ideas are put into practice. These include the following. (1) Framing the policy problem: Policy entrepreneurs raise new ways of thinking and defining policy problems (Baze and Abolafia 2002) and achieve consensus within a certain scope. (2) Brokering policy programs: In order to popularize their favored policy programs, policy entrepreneurs seek approval as much as possible by lobbying other policy actors; they try to control the political discussion to formulate a new power structure that is friendly to policy idea diffusion and strengthen the legitimacy of the new policy (Riker 1986; Waddock and Post 1991). (3) Establishing policy alliances: Policy entrepreneurs have to accumulate resources with the support of other organizations and individuals until the "opportunity window" opens. (4) Policy experimenting: There can be competition among policy entrepreneurs in the same policy area (Crowley 2003). They thus strive to prove the superiority of their programs to win the competition (Mintrom and Norman 2009).

Based on the existing literature, this article reveals the important role of policy entrepreneurs in local policy innovation using the case of health insurance policy innovations in Nanguo City as an illustration.

\section{Methods}

\section{Policy innovation in Nanguo City: establishing health insurance without an urban-rural} division

Nanguo City, located on the southeast coast of China, achieved economic prosperity during the Reform and Opening. From the 1990s onward, along with industrialization and urbanization, the city of Nanguo has transformed itself from an agricultural county relying on fruit and vegetable crops into an industrial city famous for its electrical industry and regional industrial clusters. However, high-speed economic growth and urbanization have brought many challenges. From 1985 to 2000, farmland in Nanguo City was reduced by $286.2 \mathrm{~km}^{2}$ (Zheng et al. 2003), with the proportion of agricultural production value in the regional GDP decreasing from 20 to $6 \%$; a huge number of peasants lost their land. Constant disputes and resistance followed and became more violent. Meanwhile, the economic growth attracted migrant workers, who made up $70 \%$ of the total population in 2009. In sum, significant economic, social, and demographic transitions have brought severe challenges to Nanguo City.

Nanguo City is one of the pioneers in the ongoing reform of China's health insurance programs. In the mid-1980s, it took a leading position in adjusting social insurance 
policies. In the late 1990s, the Nanguo municipal government began a policy experiment of establishing an urban-rural integrated social insurance system. In July 2008, Nanguo City was the only city in the entire province to establish a unified health insurance system by breaking the urban-rural hukou (household registration) barrier. Residents of Nanguo City, such as urban employees including migrant workers, the selfemployed, the retired, the unemployed, and the poor, were covered by one unified health insurance rather than three or even more as in other municipalities. The new health insurance system performed well in terms of efficiency and equality since it not only increased the compensation rate but also treated migrant workers as equal to local citizens. Since then, the Nanguo City government has launched some supportive policy tools, such as investing in a community health center and upgrading compensation levels, to ensure successful implementation of the new health insurance policy.

The health insurance policy innovation in Nanguo City has steadily progressed over a 10-year period. In March 1992, the Nanguo municipal government initiated the health insurance innovation autonomously even though it was not listed as a social policy reform experiment goal by the provincial government. Instead of rushing, the Nanguo municipal government aimed to achieve and establish the new health insurance policy systematically; the effective policy implementation benefited from the advanced insurance data management system (see Table 1). In 1994, the Health Insurance for Critical Illness (HICI), the foundation of the new health insurance policy, was established in Nanguo City; it worked smoothly and balanced the health insurance fund deficit in a short time. Based on this initial success, the HICI was upgraded and renamed as Basic Health Insurance (BHI) and extended its coverage to outpatient service in 2000. Meanwhile a new health insurance program, which imitated the HICI and was named Health Insurance for Hospital Care (HIHC), was launched and provided basic hospital health security for workers of privately owned enterprises. In 2004, the Nanguo municipal government set up Local Citizen Health Insurance (LCHI) under which all local citizens could receive health welfare equally, regardless of their hukou (household registration) status. The policy innovation was finally implemented as practice in 2008 with the unified health insurance system that theoretically covered every inhabitant of Nanguo City and provided equal health care that overcame the rural-urban division and worker-resident difference.

Compared to other regions, the health insurance system development in Nanguo City is taking the lead in different aspects, such as equity and coverage. First, the HIHC, established in 2000 mainly for migrant workers, not only expanded the coverage of health insurance but also benefited the migrant workers, who were consistently

Table 1 Progressive health insurance policy reform in Nanguo City

\begin{tabular}{lll}
\hline Time & Innovative policy program & Policy result \\
\hline 1994 & Health Insurance for Critical IIIness (HICl) & A new basic health insurance system for urban employees \\
2000 & $\begin{array}{l}\text { Basic Health Insurance }(\mathrm{BHI}) \text { and Health } \\
\text { Insurance for Critical IIIness }(\mathrm{HICl})\end{array}$ & $\begin{array}{l}\text { Expand the coverage of health insurance, coverage } \\
\text { for migrant workers }\end{array}$ \\
2004 & Local Citizen Health Insurance (LCHI) & $\begin{array}{l}\text { Equal treatment of rural and urban residents and } \\
\text { breaking of the urban-rural division }\end{array}$ \\
2008 & Unified Basic Health Insurance System & $\begin{array}{l}\text { Integrate fragmented health insurance policies } \\
\text { into one }\end{array}$ \\
& General Outpatient Health Security & Strengthen the "hospital care and outpatient" model
\end{tabular}


neglected in other cities. This provided a valuable experience for higher level governments to promote health reform while securing the welfare of migrant workers. Meanwhile, rather than implement the national policy, in 2004, the Nanguo municipal government launched LCHI for both local rural and urban citizens by separately establishing the New Rural Cooperative Health System and Urban Resident Health Insurance. In addition, the Nanguo municipal government joined all fragmented health insurance programs into one basic health insurance system and strengthened the "hospital care and outpatient" compensating insurance model rather than the "public pool and individual account" insurance model by upgrading gatekeeper health service at the community level.

The Nanguo municipal government benefited from these policy innovations in two ways. First, the new health insurance program, with its high quality and efficiency, became a vital part of the social security network of Nanguo City to maintain social stability. By the end of 2011, over 6 million residents in Nanguo City, including about $70 \%$ of the migrant population, had participated in the unified basic health insurance, indicating that the health insurance system in Nanguo City was able to provide basic health security for most of its residents. An insured resident who received hospital service and outpatient health care in a communal health center would be reimbursed $95 \%$ of their expenses (100\% for retired people, the ceiling was $150 ¥$ ) and $70 \%$ (no cap set) maximum of the total health fee. Second, the success of the policy innovation contributed remarkably to the political achievements of local leaders. The Nanguo municipal government gained a high reputation in health reform and was frequently praised by both the provincial government and the Ministry of Human Resources and Social Security.

Why could Nanguo City create its health insurance policy in a sustainable way and eventually achieve a unified health insurance system for its inhabitants? There are many possible reasons, such as developed economic and social conditions and its unique demographic structure with its huge number of young, healthy migrant workers. However, we argue that the key reason lies in the efforts made by policy entrepreneurs. Bureaucrats of the Social Security Department in Nanguo City (SSDNC) have played a key role in the policy innovation process.

\section{Policy entrepreneurs in policy innovation: incentive and strategy}

The process of health insurance policy innovation in Nanguo City is long and complicated. This section analyzes the incentives that encourage the administrative bureaucrats to become involved and play the policy entrepreneur role and the strategies they apply to promote policy innovation.

\section{Policy entrepreneurs in the SSDNC: bureaucrats and incentives}

Policy entrepreneurs are dedicated to investing their time, energy, personal reputation, and even property to promote policy change (Kingdom 1995:7). They are capable of changing political orientation and to making significant transformation possible (Schneider and Teske 1992). In Nanguo City, bureaucrats of the SSDNC have fully acquired these characteristics and have played the policy entrepreneurial role in health insurance policy innovation. They are local elites who know the social and economic 
environment very well; in addition, they are professional officers who have worked in the Social Security Department for years. Their work experiences cultivate the intention of policy innovation and establish channels to policy participation and communication.

Mr. Lao and Mr. Zhao are representatives of the policy entrepreneur group in the SSDNC. Mr. Lao has worked in Nanguo City for decades and knows the local social and political situation well. He is energetic and has ambitions of individual political achievement. Mr. Zhao previously worked as a lecturer at a university; he is now an expert who enjoys a high academic reputation in the areas of Chinese health insurance and health economics. Before working in the SSDNC, he had been involved in some health policy experiments in another city that enriched his policy experiences. Mr. Lao and Mr. Zhao have worked together for over 10 years and share similar idea about health insurance issues. Cooperating with other staff in the SSDNC such as Mr. Gao, who was awarded the title of the National Labor Model; Mr. Yao, who is the senior director of the policy research office; and Ms. Cao, who is the chief of the health insurance section, they built up a policy entrepreneur group that designed and brokered innovative health insurance policy programs and became the key actors in promoting policy innovations in Nanguo City.

Policy entrepreneurs are motivated by both the government power structure and their own ambitions. At the very beginning, the SSDNC was a marginal department and faced the threat of being integrated into another department since it did nothing to promote economic growth while spending government revenue on public service. As rational actors, bureaucrats in the SSDNC always try to maximize the opportunity of surviving and getting profits by drawing on various beneficial conditions (Niskanen 1971, 1973). However, compared to bureaucrats in other government departments, the bureaucrats of the less-valued and noticed SSDNC enjoy more freedom in taking policy action. They have strong incentive to strive for political achievement since if they fail they would lose nothing, given their marginal status. However, if they succeed, the SSDNC could receive more attention and even more power from local leaders. What is more, Mr. Lao, Mr. Zhao, and other policy entrepreneurs who hold on to a clear policy innovation blueprint are experienced and share the goal of transforming their ideas into policy innovations.

\section{Promoting policy innovation: policy entrepreneurs' strategies}

Policy innovation means abandoning traditional thinking patterns and breaking the existing policy equilibrium, which can bring political risks and opposition from stakeholders (Roberts and Bradley 1991). Moreover, it takes time for other policy participants to understand and identify with new ideas and policy programs. To ensure success, policy entrepreneurs need to do more than aspire toward policy innovation; they have to design feasible working plans and gain support by using proper strategies.

\section{Framing and brokering policy ideas}

Policy entrepreneurs are sensitive to policy inefficiencies and policy problems. They explain the urgent necessity of policy change to draw attention from other policy actors and provide policy substitution at the same time (Mintrom and Vergari 1996). In the early stage of health insurance reform, bureaucrats in the SSDNC were in an unfavorable situation. The SSDNC is a low-ranking and peripheral institution with a poor working environment and lack of professional staff. In order to get more attention and 
support from above, they tried to increase the importance of their work by framing the health insurance issue. Bureaucrats of the SSDNC initiated the HICI, which aimed to focus mainly on medical care reimbursement for serious illnesses and certain outpatient services. General outpatient services were eliminated, which of course decreased the health insurance contribution fee of enterprises and individuals. The new policy program was accepted by local leaders and the insured in a short time since it quickly halted the health insurance fund deficit while keeping the contribution fee at a comparatively low level. In addition, they persuaded local leaders to accept the importance of social insurance programs in maintaining social stability. Their ideas and policy programs were gradually accepted and supported by local leaders after a period of lobbying and informal advising.

The SSDNC provided some innovative policy ideas for municipal leaders to maintain social stability. One of the most important suggestions concerned the landless peasants' welfare. We told the mayor and vice deputy, "The landless peasants would move to radical resistance if their interests could not be guaranteed. But if they are covered by social insurance programs, they could get basic social security and stay away from violent action." Gradually our mayor also felt obliged to establish the social insurance program in Nanguo City. (Interview with Mr. Zhao, 12/18/2009²)

At the work conference for health insurance promotion, Li, the party secretary of Nanguo City, made the concluding remarks to the township party secretaries: "The development of social insurance follows the historical trend. We should refresh our mindset and improve social insurance policies according to the market transformation. If anyone cannot change his or her mindset, I would rather have the person who holds the changed position." (Interview with Mr. Lao, 04/07/2010)

Holding a clear policy blueprint is a powerful tool for policy entrepreneurs to receive public support (Béland 2005; Blyth 2001). Bureaucrats of the SSDNC provided a convincing blueprint for the gradual development of health insurance innovation in Nanguo City. First, they declared that it is more workable in health insurance reform to follow the law of large numbers principle and learn from developed countries' experiences rather than following the strategy of "cross the river by touching the stones." Second, they were clear that the new health insurance policy could not be accomplished with one stroke. Consequently, Mr. Zhao set the policy aim of "a unified and citizen-based basic health insurance program" while achieving the policy innovation in a progressive way, which he presented as the pizza theory ${ }^{3}$ (see Table 2). The first step was to establish a basic policy framework and united management standard for the existing fragmented health insurance programs. This should then be followed by controlling the development of health

Table 2 Three-layer pizza theory of health insurance policy

\begin{tabular}{lll}
\hline Layer & Policy program & Feature \\
\hline Third extra level & Supplementary health insurance & High quality and extra health demand \\
Second general level & Basic health insurance & Basic health security for all insured equally \\
First basic level & Social medical aid & Targeted at the most vulnerable groups \\
\hline
\end{tabular}


insurance programs with higher reimbursement rates and upgrading health insurance programs with low reimbursement rates and achieve unification step by step.

It is just like linking two running train carriages together. They (the existing health insurance programs) have to share the same policy framework, just like different train carriages running on the same track. Only when all of them reach the same benefit level can they be unified into one basic health insurance program. It is so simple, just as the only thing you need to do to link two running trains at the same speed is open the middle doors of the two. (Interview with Mr. Zhao, 12/18/2009)

\section{Design new programs and capture political opportunities}

It is crucial to seize political opportunities in the policy innovation process (Kingdom, 1995). Policy entrepreneurs in the SSDNC and policy actors inside the closed policy network are familiar with operational political rules in Nanguo City and sensitive to potential policy windows that could allow policy changes to happen. Since the 1990s, mayors and party secretaries of Nanguo City confronted two policy issues. One was how to implement the health insurance policy reform required by the central government; the other was how to expand the coverage of social insurance programs to local citizens and migrants.

In 2000, the Nanguo municipal government was urged to accomplish the political task of expanding social insurance coverage. The party secretary and mayor of Nanguo City received a letter from the provincial government in which the Nanguo municipal government was asked to serve as an example for other cities by increasing the number of social insurance participants to 1 million. This brought huge pressure to local leaders who did not want to fail in the local government competition and lose the chance of promotion, as the following speech by Secretary Tong suggests:

The provincial party committee and government are very determined about the expansion of health insurance coverage. Our provincial sectary and director have urged us to take action. Meanwhile, our neighbor cities have been advancing very rapidly. During the past year, comrade Gong (the mayor of Nanguo City) and I have been under great pressure. (Mr. Tong, Speech on the Conference of Social Insurance Work, 2002)

In the SSDNC, Mr. Lao and other policy entrepreneurs were vigilant about the opportunity though which they could acquire executive resources and power to accomplish the task and establish a new social insurance system. Led by Mr. Lao, they designed the new health insurance policy program, low contribution fee, and wide coverage according to Nanguo City's unique demographic structure in which most of the population are young, healthy migrant workers. They provide the new policy program to local leaders to avoid imprudent decision making. Mr. Lao, the vice director of the bureau, played a crucial role in marketing the program to local leaders.

I was in charge of the health insurance programs in 2002. In my opinion, designing the health insurance policy programs in Nanguo City had to follow its demographic structure. After the state council meeting of health insurance reform, I had a talk 
with Mr Zhan, the vice mayor in charge of social welfare and the direct leader of the SSDNC. I told him that the participation of migrant workers is the main obstacle to our work in expanding health insurance coverage. However, if we could insure them successfully, it would benefit the health insurance fund and solve the reimbursement deficit problem in the long run. As migrant workers, they are young and healthy and rely little on health insurance, while their contributions in turn transfer to cover the high health-care expenditures for the old. He replied: "It sounds good. We could give it a try." We reported on our new policy program to the provincial bureau of social insurance and got a positive response. (Interview with Mr. Lao, 04/07/2010)

After 1 year of preparation, mainly on upgrading the insurance data management system, the Nanguo municipal government launched the BHI and the HIHC, both of which were designed by policy entrepreneurs of the SSDNC. The former combined social funds with personal accounts and covered both hospital care and outpatient services. It aimed to insure employees in government and state-owned enterprises. The HIHC aimed to insure workers, mainly migrants, from privately owned companies. Both health insurance programs were based on employees' working status, not on the division of the population into urban and rural residents. Moreover, the contribution fee, $2 \%$ of the last year's average salary in Nanguo City, was significantly lower than the average, which in other cities is normally $8 \%$ of the average salary. The new policy reduced the social welfare burden on enterprises and made them more willing to participate by providing comparatively more generous compensation.

Consequently, this helped local leaders expand health insurance coverage without raising serious resistance from enterprises and local governments at lower level. By the end of 2000, the coverage of the new health insurance policy had risen from 0.2 to 0.88 million. Along with the success of ongoing pension reform, this relieved leaders of Nanguo City from political pressure from above and successfully drew the attention of the central government. The health insurance policy innovation in Nanguo City was presented as a leading example in the national health insurance reform. In return, leaders of Nanguo City upgraded the political ranking of the SSDNC and valued the health insurance policy innovation much more with fiscal and institutional support.

\section{Make alliances and defeat the opposition}

Policy entrepreneurs establish and maintain political alliances, seek support from internal and external agents, and avoid political risks to ensure the success of political innovations (Christopoulos 2006; Mintrom and Vergari 1996; Wilson 1989). It was hard for the SSDNC to maintain policy innovations alone because of its marginal role in the government. Policy entrepreneurs in the SSDNC needed to seek alliances with the government and the public who share the same interests and could support policy innovations.

First, they built up an interest-based coalition with the Bureau of Finance, the Bureau of Industry and Commerce Administration, and the Bureau of Local Taxation inside the municipal government. Policy entrepreneurs were fully aware of the Bureau of Finance's concern regarding minimizing the public expenditures for health insurance reform. In order to win support from the Bureau of Finance, Mr. Lao and Mr. Zhao explained their new policy to the bureau's officials in detail and guaranteed that the new health insurance would be selfsufficient. The SSDNC also maintained a good relationship with the Bureau of Finance by 
inviting it to participate in the design of the LCHI in 2002. To attract the interest of the Bureau of Industry and Commerce Administration and the Bureau of Local Taxation, policy entrepreneurs showed that the expansion of social insurance raised the revenue of both bureaus by collecting contribution fees and providing verification services.

Second, through the efforts of policy entrepreneurs, the health insurance policy innovation also received support from the Ministry of Human Resources and Social Security with policy entrepreneurs' efforts. Policy entrepreneurs adopted flexible strategies when dealing with central government authorities. In the 1990s, Mr. Lao, vice director of the SSDNC, began to lobby the Ministry of Human Resources and Social Security and maintain a close private relationship with officials of the Ministry of Human Resources and Social Security. During the policy innovation, the SSDNC always requested consultations with and information from the Ministry of Human Resources and Social Security. Policy entrepreneurs also invited officials of the Ministry of Human Resources and Social Security to conduct investigations in Nanguo City and made lobbys and explanations more effectively.

"Actually, we told them that the SSDNC is following the national policy. ... When the Chief of the Ministry of Human Resources and Social Security comes, we can easily persuade them that we are doing the right thing by showing our achievements" (Interview with Mr. Yao, 12/18/2009).

The minister and other high-ranking officers of the Ministry, who Mr. Zhao consistently provides with consultations and suggestions, support his ideas and attitudes on health insurance reform.

Policy entrepreneurs also sought understanding and support from the public. Before the launch of new health insurance policies, policy entrepreneurs publicized the advantages of the new health insurance policy through the mass media, such as radio broadcasts, and newspapers. After retiring from the leading position in the SSDNC, Mr. Lao even published a magazine titled The Social Insurance in Nanguo City and sent free copies to all villages in order to reach as many local residents as possible. Policy entrepreneurs also placed a high value on policy implementation to ensure the initial success of the health insurance policy innovation, which can benefit the insured and gain their support in return. Moreover, they held exhibitions of health insurance reform achievements to raise public awareness of the benefits of the health insurance policy innovation.

As for other stakeholders, policy entrepreneurs adopted different strategies to deal with disputes and achieve accomplishments. To deal with enterprises with health insurance concerns, they soothed employers' nerves on one hand and applied pressure on the other. First, policy entrepreneurs asked employers to pay the insurance fee for occupational injuries, the major concern of company owners, and the health insurance fee together. The contribution fee is comparatively low, less than $1.5 \%$ of the wage expenditure on average, and affordable for most of small-sized privately owned enterprises. As a result, enterprise owners were more willing to participate than before. What is more, the regulation of health insurance participation on enterprises was not strict that could help to decrease potential resiliency in policy implementation. Policy entrepreneurs of the SSDNC also used their personal network to urge private-sector owners to accept the new health insurance policy and get the expanded insurance coverage.

To be honest, we have mobilized all possible resources to ensure the policy implementation. We established the pension insurance in advance and then packed 
the health insurance with it to get better acceptance. Sometimes we did encounter some companies in the town that refused to pay the health insurance fee. I solved this problem by talking to the local leaders. The local leaders would put pressure on those bosses by asking the bosses not to embarrass them. By doing so, an atmosphere for accepting the new policies was created. (Interview with Mr. Lao, 04/06/2010) To avoid complaints from different insured groups, policy entrepreneurs showed particular concern for the benefits of employees in state-owned companies. Workers in public sectors, including employees of state-owned enterprises, were entitled to gold-card membership, which included the privilege of securing outpatient services. Civil servants especially were promised that their health welfare would not be reduced under the new health insurance policy compared to the gong fei yi liao

(Free Medical Service). New participants, mainly migrant workers, could receive basic health security at a low contribution fee. All the insured would benefit from the policy innovation while nobody would lose. Thus resistance from residents was minimized.

\section{Mark the highlights and seek decision makers' approval}

A common strategy adopted by policy entrepreneurs is to eliminate decision makers' doubts through effective policy implementation (Mintrom and Norman 2009). The key for successful policy innovation is attracting local leaders and acquiring their support and acknowledgment since they hold the power to make the final decision. Fully aware of the importance of the decision maker's attitude, Mr. Lao, Mr. Zhao, and other policy entrepreneurs took an active role in persuading decision makers. They assured the party secretary and the mayor of Nanguo City that if implemented effectively, the new health insurance policy could solve social problems and bring political achievements.

Policy entrepreneurs created the image of "limited budget but high efficiency" for new health insurance policy implementations that acquired local leaders' approval. Based on the local demographic structure, the new health insurance policy could operate smoothly even with limited financial support. In addition, policy entrepreneurs in the SSDNC made efforts to strengthen their executive power in order to ensure the policy implementation. They upgraded the insured data management system and imported new management methods of archiving, both of which dramatically elevated executive efficiency in the SSDNC. New work procedure regulations were also applied in the SSDNC following the organizational structure adjustment to improve its professional capacity and reduce working errors. The office of policy publicity and the office of policy research, both newly established, have become vital actors in new health insurance policy implementation.

The successful policy implementation not only relieved political pressure on local leaders and maintained social stability but also generated conspicuous political achievements that contributed to local leaders' promotion and drove them to invest more resources to further the health reform. In 2005, the insured data management system that Mr. Lao and Mr. Zhang had designed for the social security administration won the Provincial Science and Technology Progress Award. This was the first time that Nanguo City earned such an honor. The policy innovation also brought commendations from other cities and even the central government. This attracted the attention of the vice minister of the Department of Human Resources and Social Security and leaders of provincial government, who then visited Nanguo City. The SSDNC also 
earned many prizes from the provincial government; even Prime Minister Wen Jiabao gave his approval after hearing the Nanguo City mayor's report. In July 2007, the Vice Deputy of Nanguo municipal government was invited to share its health insurance policy innovation experience to the national representatives at the national conference of urban-rural resident health insurance development, bringing even more fame to the leaders of Nanguo City. Due to policy entrepreneurs' sustained efforts, the SSDNC brought many highlights to local leaders' list of political achievements.

In return, local leaders in Nanguo City also showed more concern regarding health insurance policy innovation. The political ranking of the SSDNC as well as its budget was raised several times. Policy entrepreneurs in the SSDNC took advantage of this and successfully made the SSDNC one of the core departments in the municipal government by lobbying the party secretary. In 2008, the SSDNC becomes the only department in the entire province to keep its independent status of being in charge of social insurance policies. In other municipalities, the Department of Social Security was removed and merged into the Department of Human Resources during the reconstruction of government offices.

Our director listed three reasons to convince Sectary Liu to keep the SSDNC. First, the SSDNC itself is a political highlight. There would be no highlight anymore after removing it. Second, the SSDNC has established a unified insurance system for both urban and rural residents that was taken as an example of policy innovation by the central government. The policy innovation might be eliminated by dismissing the SSDNC. Third, the SSDNC is also an example for other municipal government departments in terms of high efficiency and good public reputation. It has gained massive support due to its excellent performance from residents in Nanguo City. It is another political highlight of the Nanguo municipal government that would be lost if the SSDNC were merged into another department. Consequently, the SSDNC should retain its distinctive status. (Interview with Mr. Zhao, 03/26/2010)

In July 2008, Mr. Zhang, together with other policy entrepreneurs, suggested a new health insurance policy that combined basic employee health insurance with urban-rural resident health insurance into one basic health insurance system. All residents of Nanguo City, including employees, unemployed, self-employed, and rural residents, would be covered by this unified health insurance program. Regardless of work status, residents would share equal contribution fee rates and reimbursement standards. The successful policy implementation not only solved the social problem of increasing demand for health security in Nanguo City without extra expenditure but also helped the Nanguo municipal government gain the reputation of treating migrant workers as equal to local citizens. Because of its achievements in social security reform, in 2009, Nanguo City was awarded the title of "National Model City of Social Development" by the State Council. The SSDNC also benefited from this policy innovation in that it became an important institution in maintaining social stability and acquired a dominant influence in the area of social policy.

During their communications with different local leaders, policy entrepreneurs seized the opportunity with perfect timing and were able to propose new feasible policy alternatives. In addition, policy programs provided in the policy innovation process also met local leaders' demand for political achievement. Both were core reasons for local leaders continually supporting the policy innovation over more than a decade. 
Why did our health insurance reform maintain progressive development? I believe there is a certain degree of intersection of interests between bureaucrats and political leaders. We are technical bureaucrats who should tell the political leaders what can be done. We should provide them with policy plans that can both meet the technical requirements and satisfy their political demands. If we can provide them with political highlights that match the development of governing techniques, they would be delighted to gain political benefits and give their support in return. Meanwhile, we can promote policy changes according to scientific rules. (Interview with Mr.

Zhao, 12/18/2009)

\section{Results}

Understanding the local policy innovation process: bureaucrats as policy entrepreneurs

Policy innovation is a complicated political process that involves various interactions among different policy actors. The case of health insurance policy innovation in Nanguo City shows that policy innovation cannot be attributed to local government as a whole or to some key leaders; instead, bureaucrats are policy entrepreneurs who bring the policy innovation into reality. They have advantages in expertise and information that are the key factors to fostering policy innovation in local government. Meanwhile, they are not neutral, routinized, or passive executors but innovators who enthusiastically promote policy reform.

Bureaucrats familiar with governance patterns hold communication channels with decision makers and thus have more opportunities to influence policy innovation at each stage. At the early stage, they can identify social problems, frame and raise policy alternatives, and promote their policy ideas into policy agenda setting. As policy actors inside the closed policy network, they are capable of capturing or even creating political opportunities to gain support from other policy actors. In particular, they can mobilize administrative resources and adopt different strategies to persuade local leaders to launch the new policy programs and promote the policy innovation implementation. In Nanguo City, bureaucrats in the SSDNC are vital actors in promoting health insurance policy change. They are not only advocates who infuse "the problems stream, policies stream, and the politics stream" (Kingdom 1995) but also policy innovators who design the policy programs.

Constrained by the centralization of decision power and the closed policy network, bureaucrat policy entrepreneurs have to seek both technical feasibility and political feasibility of policy innovation. In order to affect the policy-making process under an authoritarian regime, social policy entrepreneurs generally aim to expand their voice through mass media and by taking aggressive strategies to get public attention since they have few opportunities to join the closed policy network. In contrast, bureaucrat policy entrepreneurs tend to take actions that are more moderate. In order to gain as much support from stakeholders as possible, they make alliances, stress the sharing of policy benefits, and emphasize the technical feasibility of the policy. In addition, since bureaucrats do not hold the power to make the final decision, they have to lower the political risk and persuade decision makers by framing policy issues and through effective policy implementation. Policy innovation promoted by bureaucrat policy entrepreneurs follows the "bottom-up" process that gradually accomplishes the establishment of 
political feasibility step by step. This differs from "top-down" policy innovation, which is always initiated by local political leaders and can flourish only in a short period.

\section{Discussion and conclusions}

Local policy innovation is a dynamic and complicated decision-making process. Local leaders and administrative bureaucrats are the key policy agents in the process. In response to the expectation of political achievements from above, local leaders have the motivation to launch social policy innovation; however, they do not necessarily possess the expertise that is necessary for the configuration of innovative ideas and feasible policy programs. In contrast, bureaucrats, equipped with technical expertise and adequate information, are willing and able to be the policy entrepreneurs who foster and promote policy innovation.

This article contributes to Chinese local government studies in many aspects. First, it reveals the complexity of daily operations inside local governments. There is no doubt that local governments dominate the policy-making process under the authoritative regime. However, the policy actors who exert an impact in the policy process are not confined to the local leaders. Identifying the different policy actors and examining their interactions are necessary in order to gain a comprehensive understanding of the local policy-making process in China. Second, in China, bureaucrats' work should not simply be deemed as neutral, routinized, and executive; they are professionals and familiar with governance rules, which makes them vital policy actors in driving policy innovations.

Moreover, this article contributes to the development of policy entrepreneur theory. First, through the analysis of bureaucrat policy entrepreneurs, it demonstrates the applicability of policy entrepreneur theory to Chinese cases. Second, it can enrich research on Chinese policy entrepreneurs by showing the concrete ways that policy entrepreneurs influence policy changes. This article draws attention to policy entrepreneurs inside Chinese governments, a subject generally neglected in the existing literature. Finally, this case can be useful to comparative studies of different types of policy entrepreneurs by showing the roles and strategies that Chinese bureaucrats take in the policy innovation process. Compared to policy entrepreneurs outside the government, bureaucrats are familiar with governance rules in China, possess communication channels with decision makers, and are thus more able to directly influence the design and selection of policy alternatives. They also tend to take moderate actions to avoid the risks brought by innovations. Unlike political leaders as policy entrepreneurs, bureaucrat policy entrepreneurs cannot make final decisions. As a result, they turn to establishing political alliances and persuasion to expand the impact of the innovation policy. They prefer to take strategies that influence policy innovation gradually and indirectly.

It should be noted that the results gained from one single case needs further examination since policy innovations can occur and vary at all levels of government as well as different policy areas. Further studies could focus on the following two aspects. First, new research could compare policy innovations in different policy areas and different government levels. Examining the roles played by different policy actors and their interactive strategies is needed, which could contribute to the theorization of policy studies in China. Second, scholars could compare Chinese policy innovation with cases from other countries by focusing on policy entrepreneur types and their strategies to enrich policy entrepreneur theory. 


\section{Endnotes}

${ }^{1}$ This article takes policy innovation as policy changes that are new to the public organization (Walker 1969). The success of a policy innovation indicates that the innovative policy program has been accepted and implemented.

${ }^{2}$ The number indicates the date of the interview, as do the other following numbers.

${ }^{3} \mathrm{Mr}$. Zhao believes that the construction of the health insurance system can be conducted in three layers. The aims of the first and second layers are to secure wide coverage of basic needs and justice. These two layers should be wide and broad, like the crust of a pizza. The third layer should be supplements, like the toppings on the pizza, which serves participants with higher health demands.

Competing interests

The authors declare that they have no competing interests.

\section{Authors' contribution}

YZ carried out the case study, conducted thefield work and drafted the manuscript. DX conducted the interviews, collected and organized all the data and participated in the manuscript drafting. Both authors read and approved the final manuscript.

\section{Authors' information}

Zhu Yapeng is Research Fellow at the Center for Chinese Public Administration Research and Professor at the School of Government, Sun Yat-Sen University. His research focuses are on the policy-making process and social policy in China.

Xiao Diwen is a PhD student at the School of Government, Sun Yat-sen University. His research focuses on the social policy in China.

\section{Acknowledgements}

This research was supported by the 211 project and the 985 project of Sun Yat-sen University and by "Expanding Citizens' Orderly Political Participation: Strategy, Path and Countermeasures" Research Project (Project No. 12 and ZD040), "Social Stability System Construction in the Context of Urban-rural Integration" Research Project (Project No. 13 and ZD041), and "Asset-based Social Policy" Research Project (Project No. 14JJD630014). Thanks to the anonymous reviewers for their pertinent comments.

Received: 26 July 2015 Accepted: 9 September 2015

Published online: 24 September 2015

\section{References}

Baze, Bien, and Mitchel Abolafia. 2002. Bureaucratic entrepreneurship and institutional change: a sense-making approach. Journal of Public Administration Research and Theory 12(4): 525-552.

Béland, Daniel. 2005. Ideas and social policy: an institutionalist perspective. Social Policy and Administration 39(1): 1-18.

Blyth, Mark. 2001. The transformation of the Swedish model: economic ideas, distributional conflict, and institutional change. World Politics 54(1): 1-26.

Chen, Tianxiang. 2002. The roles and the ways of institutional innovation of local government in China. Journal of Sun Yat-sen University (Social Science Edition) 3: 111-118.

Chen, Xuelian, and Xuedong Yang. 2009. Promoting local government innovations: local Cadres' view. Journal of Public Management 3: 1-11.

Cheung, Peter TY, Jae Ho Chung, and Zhimin Lin. 1998. Provincial strategies of economic reform in Post-Mao China: leadership, politics, and implementation. Armonk, NY: M. E. Sharpe.

Christopoulos, Dimitrios C. 2006. Relational attributes of political entrepreneurs: a network perspective. Journal of European Public Policy 13(5): 757-778.

Crowley, Jocelyn. 2003. The politics of child support in America. New York: Cambridge University Press.

Doig, Jameson W, and Erwin C Hargrove. 1990. Leadership and innovation: entrepreneurs in government. Baltimore, MD: Johns Hopkins University Press.

Glor, Eleanor D. 2001. Key Factors Influencing Innovation in Government. The Innovation Journal 6(2): 1-20.

Hammond, Daniel R. 2013. Policy entrepreneurship in China's response to urban poverty. Policy Studies Journal 41(1): 119-146.

He, Zengke. 2007. Legitimation and Chinese local government innovation: a primary empirical study. Journal of Yunnan Administration College 2: 8-13.

Heilmann, Sebastian. 2007. Policy experimentation in China's economic rise. Studies in Comparative International Development 43(1): 1-26.

Heilmann, Sebastian. 2008. From local experiments to national policy: the origins of China's distinctive policy process. The China Journal 59: 1-30.

Huitema, Dave, and Sander Meijerink. 2010. Realizing water transitions: the role of policy entrepreneurs in water policy change. Ecology and Society 15(2): 26-35.

Jin, Hehui, Yingyi Qian, and Barry Weingast. 2005. Regional decentralization and fiscal incentives: federalism, Chinese style. Journal of Public Economics 89: 1719-1742. 
King, Paula J, and Nancy C Roberts. 1992. An investigation into the personality profile of policy entrepreneur. Public Productivity and Management Review 16(2): 173-190.

Kingdom, John. 1995. Agendas, alternatives and public policies. New York: Harper Collins.

Lewis, Eugene. 1980. Public entrepreneurship: toward a theory of bureaucratic political power. Bloomington: Indiana University Press.

Mertha, Andrew. 2009. "Fragmented authoritarianism 2.0": political pluralization in the Chinese policy process. The China Quarterly 200: 995-1012.

Mintrom, Michael. 1997. Policy entrepreneurs and the diffusion of innovation. American Journal of Political Science 41(3): 738-770.

Mintrom, Michael, and Phillipa Norman. 2009. Policy entrepreneurship and policy change. The Policy Studies Journal 37(4): 649-667.

Mintrom, Michael, and Sandra Vergari. 1996. Advocacy coalitions, policy entrepreneur, and policy change. Policy Studies Journal 24(3): 420-434

Niskanen, William A. 1971. Bureaucracy and representative government. Chicago, IL: Aldine Atherton.

Niskanen, William A. 1973. Bureaucracy-Servant or Master? Lessons from America. London: Institute of Economic Affairs.

Oi, Jean C. 1992. Fiscal reform and the economic foundations of local state corporation in China. World Politics 45(1): 99-126.

Oi, Jean C. 1995. The role of local state in China's transitional economy. The China Quarterly 144: 1132-1149.

Oi, Jean C. 1998. The evolution of local state corporatism. In Zouping in transition: the process of reform in North China, ed. G Andrew, 35-61. Cambridge: Harvard University Press.

Qian, Yinyi, and Gérard Roland. 1998. Federalism and the soft budget constraint. The American Economic Review 88(5): $1143-1162$.

Qiu, Haixiong, and Jiannian Xu. 2004. Governmental behaviors in the industry cluster technical innovation. Management World 10: 36-46.

Riker, William. 1986. The art of political manipulation. New Haven, CT: Yale University Press.

Roberts, Nancy C. 1992. Public entrepreneurship and innovation. Policy Studies Review 11(1): 55-74.

Roberts, Nancy C, and Raymond T Bradley. 1991. Stakeholder collaboration and innovation: a study of public policy initiation at the state level. The Journal of Applied Behavioral Science 27(2): 209-227.

Rogers Everett M. 1995. Diffusion of Innovation (4th ed). New York: Free Press.

Saich, Tony. 2008. Providing public goods in transitional China. New York: Palgrave.

Schneider, Mark. 1989. The competitive city: the political economy of Suburbia. Pittsburgh, PA: University of Pittsburgh Press.

Schneider, Mark, and Paul Teske. 1992. Toward a theory of the political entrepreneur: evidence from local government. The American Political Science Review 86(3): 737-747.

Shi, Jinchuan, and Ruiping Xie. 2002. The model of local development and economic institution transformations. Academic Monthly 5: 49-55.

Teodoro, Manuel. 2009. Bureaucratic job mobility and the diffusion of innovations. American Journal of Political Science 53(1): 175-189.

Waddock, Andra A, and James E Post. 1991. Social entrepreneurs and catalytic change. Public Administration Review 51(5): 393-401.

Walder, Andrew G. 1995. Local government as industrial firms: an organizational analysis of China's transitional economy. American Journal of Sociology 101(2): 263-301.

Walder, Andrew G. 1998. The county government as an industrial corporatism. In Zouping in transition: the process of reform in North China, ed. G Andrew, 62-85. Cambridge: Harvard University Press.

Walker, JL. 1969. The diffusion of the innovations among the American State. The American Political Science Review 63(3): 880-899.

Wang, Hansheng, and Yige Wang. 2009. Target management responsibility system: the practice logic of the party-state in rural China. Sociological Studies 2: 61-90.

Weissert, Carol S. 1991. Political entrepreneurs, policy opportunists, and legislative effectiveness. American Politics Research 19(2): 262-274.

Wilson, James Q. 1989. Bureaucracy: what government agencies do and why they do it. New York: Basic Books.

Wu, Jiannan, Ma Liang, and Yang Yuqian. 2007. The motivations, features and political achievements of Chinese local government innovations: a text analysis of multiple cases of innovations and excellence in Chinese local governance. Management World 8: 43-51.

Wu, Jiannan, Ma Liang, Su Ting, and Yuqian Yang. 2011. Typology and characteristics of government innovation: a multi-case study of winning programs of the innovations and excellence in Chinese local governance. Journal of Public Management 8: 94-103.

Wu, Jiannan, Ma Liang, and Yuqian Yang. 2013. Innovation in the Chinese public sector: typology and distribution. Public Administration 91(2): 347-365

Yang, Xuedong. 2008. Ten issues on Chinese local governance innovations. Journal of Public Management 1: 16-26. Yang, Xuedong. 2011. China local governments reform in the past ten years. Studies of Public Management 1: 16-26.

Zhang, Jun, et al. 2007. Why does china enjoy so much better physical infrastructure. Economic Research Journal 3: 4-19.

Zheng, Yanting, et al. 2003. The characteristics of peri-urbanization region: a case study of Nanguo municipality in Nanguo Province. Geographical Research 6: 760-768.

Zhou, Li'an. 2008. Local governments in transition: cadre incentives and local governance. Shanghai: Gezhi Publisher.

Zhu, Xufeng. 2008. Strategy of Chinese policy entrepreneurs in the third sector: challenges of 'technical infeasibility'. Policy Sciences 41(4): 315-334.

Zhu, Yapeng. 2012. Policy entrepreneur, civic engagement and local policy innovation in China: housing monetarisation reform in Guizhou Province. Australian Journal of Public Administration 71(2): 191-200.

Zhu, Yapeng. 2013. Policy entrepreneurship, institutional constraints, and local policy innovation in China. The China Review 13(2): 97-122. 